\section{Research Square}

Preprints are preliminary reports that have not undergone peer review.

They should not be considered conclusive, used to inform clinical practice, or referenced by the media as validated information.

\title{
Effects of regulated dry season irrigation on tree water use, root zone moisture dynamics and yield of cacao in a rainforest zone of Nigeria
}

Samuel Agele ( $\nabla$ soagele@futa.edu.ng )

Federal University of Technology

Ademola agbona

Federal University of Technology

abel ogunleye

Federal University of Technology

\section{Research Article}

Keywords: Cacao, water use, crop coefficient, irrigation, dry season, climatic stress, rainforest

Posted Date: February 3rd, 2022

DOI: https://doi.org/10.21203/rs.3.rs-1306540/v1

License: @) (1) This work is licensed under a Creative Commons Attribution 4.0 International License. Read Full License 


\section{Abstract}

A field trial was conducted to investigate the effects of regulated dry season irrigation on tree water use, root zone moisture dynamics and yield of cacao in a rainforest zone of Nigeria. Following cessation of rainfall in November, irrigation commenced from December 2017 to May 2018 . Irrigation amount was computed based on cumulative class A Pan evaporation. Irrigation treatments were coded as IrT1, IrT2 and IrT3, consisting of water application using EPan *Pan coefficients $(\mathrm{Kcp})$ of 1.0; 0.70 and 0.50 (9.6, 6.8 and $4.8 \mathrm{l} /$ tree/day). Irrigation water applied at 5-days interval was discharged via point source emitters ( $2.8 \mathrm{I} / \mathrm{h}$ discharge rate $)$ on drip lines laterally installed per row of trees. Irrigation requirements were on the average, $4.49,3.14$ and $2.44 \mathrm{~mm}$, total water applied per irrigation events were $1009.88,706.92$ and $504.94 \mathrm{~mm}$ per plot ( $225 \mathrm{~m}^{2}$ ), total seasonal water applied were 33858,23701 and $16929 \mathrm{~mm}$, and soil moisture contents were 52,45 and $28 \%$ for the respective IrT1, IrT2 and IrT3. Tree evapotranspiration (ETc) were $4.54,3.19$ and $2.32 \mathrm{~mm} /$ day while seasonal sums were 809, 566 and $404 \mathrm{~mm}$ while the ratio of ETc to EPan were $0.9,0.69$ and 0.53 for IrT1, IrT2 and IrT3. Tree water use efficiencies were 0.3 and $0.04 \mathrm{t} / \mathrm{mm}$ for Y/ETc and 0.16 to $0.19 \mathrm{~kg} / \mathrm{mm}$ for Y/Irrigation respectively. Cacao pod and bean yields were $35.4,22.1$ and $10.3 \mathrm{t} / \mathrm{ha}$ and $2.29,1.37$ and $1.03 \mathrm{t} /$ ha while yields decreased by 60 and $40 \%$ under IrT3 and IrT2 compared with IrT1. The study identified suitable Pan coefficients for scheduling irrigation during the dry season for cacao, full irrigation (EPan*1.0) applied at $9.6 \mathrm{l} /$ tree/day will be needed to replenish soil water depletion to satisfy crop consumptive water use ( transpiration and soil evaporation components). The low pressure gravity-drip irrigation system alleviated climate stress during the dry season and improved cacao performance in a tropical rainforest environment.

\section{Introduction}

Cocoa (Theobroma cacao L.) is an important perennial fruit tree with an estimated annual world production of 3.2 million tonnes (FAO, 2012). Within the cocoa-growing belt of West Africa, sale of cocoa beans is a major foreign exchange earner, the cocoa sector employs millions of smallholder farmers (small farm sizes ranging from 0.5 to 5.0 hectare (ha) and contributes about 70-100 \% of their annual household incomes. In Nigeria, the main cocoa-producing areas are concentrated in the rainforest of the southern part of the country where an estimated 1.45 million hectares is cultivated. The productivity is 250 $\mathrm{kg} / \mathrm{ha}$, a yield level that is lower than those from Cote d'Ivoire and Indonesia (bean yields ranging from 600 to $1000 \mathrm{~kg} / \mathrm{ha}$ respectively). In the smallholder cocoa farms of West Africa, farm sizes are small ranging from 0.5 to 5.0 hectare using low external inputs. The perrenial fruit tree species of the rainforest of Nigeria: Cacao (Theobroma cacao), Coffee (Coffea spp) and Kola (Kola spp.) are characterized by deciduous growth habit but are cultivated under rainfed conditions (Opeke, 2006, Charles et al., 2019)

Global warming and drought and other climate-related disasters are tied to the changing climate, extreme and variability of the weather (UFCCC, 2004, IPCC, 2014). The frequency and severity of drought event including ( 1.5 to $2^{\circ} \mathrm{C}$ ) warming are expected to increase in the near future as result of the decrease of regional precipitation and the increase in evapotranspiration driven by global warming (Sheffield et al., 2012, Trenberth et al., 2014,Tombesia et al., 2018). Among natural hazards, drought ranks first in terms of the number of people directly affected (Trenberth et al., 2014). The changing climatic events has implications for agriculture food security, economies, and welfare of the society and ecosystems (Grayson, 2013, Agele, 2021). Projections of climate change have pointed to an increase in mean temperature (c $2^{\circ} \mathrm{C}$ by 2080) and potential evapotranspiration, decrease in precipitation and crop (actual) evapotranspiration under future scenarios and uncertainties (Trenberth et al., 2014, Tombesia et al., 2018). This implies future yield decreases which can be associated with enhanced heat and water stress under future climate conditions. Thus, climate Change (temperature and rainfall) scenarios for the rainforest of Nigeria which have been variously constructed using climate models have indicated variabilities in rainfall pattern (amount, distribution, onset and cessation dates) and elevated maximum and minimum temperatures. These projected climatic changes will exacerbate soil moisture and thermal stresses during the dry season with implications for crop performance (Trenberth et al., 2014, Tombesia et al., 2018, Agele, 2021).

Cocoa is cultivated as a rainfed crop, and it is highly sensitive to soil and weather conditions of low rainfall, soil and air moisture deficit and temperature stresses (Opeke, 2006, Zuidema et al., 2005, Charles et al., 2019). The changing growing environmental conditions (marginal soils and extreme weather events) impose constraints on cacao growth and productivity. In order to alleviate the constraints imposed by changing growing environmental conditions (marginal soils and extreme weather events) on cacao productivity, it is imperative to develop climatic-stress adaptive strategies for the fruit tree-based agroforestry systems of the rainforest tropics in the wake of changing climate/weather conditions (climate change and weather variabilities).

The FAO Penman-Monteith equation, is accepted worldwide as the standard method for estimating reference evapotranspiration (ETo). The reference evapotranspiration (ETo) is a measure of the evaporative demand of a given environment and thus crop consumptive water use which is the sum of evaporation from soil and plant transpiration from the field (Penman, 1948, Doorenbos and Pruit, 1977, Ventura et al., 1999, Allen et al., 2005). The procedures to calculate ETo from radiation, wind, humidity and temperature data are presented in the FAO Paper No. 56. The standard procedure for estimating evapotranspiration is documented in the FAO I\&D No. 56, where a list of Kc values for each crop and developmental stage is provided. This Kc approach has been used to obtain reference evapotranspiration (ETo) and crop consumptive water use (ETc) for arables, trees and vines (Allen et al., 1998, Ferreira, 2017). The ratio between ET and ETo, is defined as a crop coefficient $(\mathrm{Kc})$. Thus, if $\mathrm{Kc}$ is known, the ETc is calculated as:

$\mathrm{ETC}=\mathrm{Kc} \mathrm{ETo} \ldots \ldots \ldots . .1$

The FAO-56 dual crop coefficient approach (Allen et al., 1998, Allen and Pereira, 2009) also describes the relationship between crop evapotranspiration (ETc) and reference evapotranspiration (ET0) by separating the single Kc into the basal crop (Kcb) and soil water evaporation (Ke) coefficients. In the FAO-56 single crop coefficient approach, the effect of both crop transpiration and soil evaporation are integrated into a single crop coefficient (Kc). However, crop evapotranspiration (ETc) estimation is more accurate by dual crop coefficient approach than the single crop coefficient approach, the dual crop coefficient approach uses more parameters and take soil practices and crop characteristics into consideration (Monteith, 1973, Ventura et al., 1999, Zhang et al., 2013). In the dual approach a daily basal crop coefficient (Kcb), representing primarily the plant transpiration, and a daily soil evaporation coefficient (Ke) are considered separately according to the equation: 


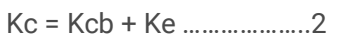

$\mathrm{ETC}=(\mathrm{Kcb}+\mathrm{Ke}) \mathrm{ETo}$

$\mathrm{Kcb}$ is a transpiration coefficient and $\mathrm{Ke}$ is an evaporation coefficient. The Kcb and Ke are the basal crop and the soil evaporation coefficients. For the dual Kc method, Ks applies only to transpiration ( $\mathrm{Tr}$ ) and provides actual transpiration (Ta). The values of Ks are obtained using its relationship with measured water stress indicators. The FAO procedure for estimating crop consumptive use requirements provides a list of Kc values for each crop and developmental stage. In the Kc approach both crop transpiration and soil evaporation are timely averaged into a single coefficient (Kc) commonly used to obtain the ETc for various crops. The FAO No. 56 Publication offers the option of differentiating E from Tr by using a dual crop coefficient approach.

The estimates of crop water requirements (ETc) are derivable from the product of potential evapotranspiration of a reference crop (ETo) using a crop factor (kc). Based on these relations:

$\mathrm{ETc}=\mathrm{ETo} * \mathrm{kc} \ldots \ldots \ldots . . . . .4$

The crop coefficient $\mathrm{kc}$ is estimated as:

$\mathrm{kc}=\mathrm{ETo} / \mathrm{ETC} \ldots \ldots . .5$

The crop coefficient $(\mathrm{Kc})$ is based on a theoretical understanding of the processes of transpiration and evaporation from a tall crop, and assumes full crop cover or frequent wetting of the soil surface. Allen et al. (1998) suggested a Kc value of 1.0-1.05 for a cocoa crop with a complete canopy.

Information is inadequate on the actual water use (ETc) of cocoa on the field (Carr, 2011). Estimated values of ETc ranging from 3 to $6 \mathrm{~mm} /$ day during rains and less than $2 \mathrm{~mm}$ /day in the dry season have been reported for cocoa (Penman, 1948). Field data (based on the sap flow method) suggest ETc rates of less than $2 \mathrm{~mm} /$ day for cocoa crop with a complete canopy, this appear to be low compared with potential ETo estimate of 3-5 mm $\mathrm{d}^{-1}$ using Penman equation (Penman, 1948). In a simulated El Ni ${ }^{2}$ no drought experiment reported by Moser et al. (2010) in Indonesia, there were no significant differences in cocoa leaf, stem and branch wood, or fine root biomass production between the rainfed control treatment and the one in which rain through-fall was reduced by $70-80 \%$ (for dry soil profile to permanent wilting point during the year). The combined average rate of water use by both cocoa and Gliricidia sepium (measured using heat dissipation sap flux sensors) was $1.3 \mathrm{~mm} . \mathrm{d}^{-1}$ in the protected plots reduced rain through-fall (rainfall reduction between $70-80 \%$ ) and $1.5 \mathrm{~mm} \mathrm{~d}^{-1}$ in the control (70\% of which was from the cocoa trees). These crop water use values were described as low (Kohler et al., 2010). Over a consecutive 18-day period, transpiration average was equivalent to $1.31 \mathrm{~mm} \mathrm{~d}^{-1}$, (about 10 litres per tree per day) compared with a Penman potential ETo estimate of 3-5 $\mathrm{mm} \mathrm{d}^{-1}$ which equates to a crop factor (Kc) of about 0.3 (Penman, 1948, Moser et al., 2010). The reports of cocoa water use and yield production when grown as mixed crop with coconut and once a week irrigation during November-December, once every six days during January-March and once in four to five days during April-May with $175 \mathrm{I}$ water tree ${ }^{-1}$. Maximum yields were obtained when cocoa was drip irrigated with $20 \mathrm{I}$ tree ${ }^{-1}$ day ${ }^{-1}$ and the total irrigation amount was $175 \mathrm{I}$ per tree. Assuming a planting density of 1600 trees ha ${ }^{-1}(2.5 \mathrm{~m} \times 2.5 \mathrm{~m})$ these figures equate to water use values of 5.6-7.0 $\mathrm{mm} \mathrm{d}^{-1}$ or 3.9-4.8 $\mathrm{mm} \mathrm{d}-1$, and 2.2 or $3.2 \mathrm{~mm} \mathrm{~d}^{-1}$ at 1100 trees ha $^{-1}(3 \mathrm{~m} \times 3 \mathrm{~m})$ under drip irrigation. No estimates of the yield benefits are given or the total quantity of water to be applied over a season. Based on field trials by Diczbalis et al. (2010), the annual irrigation requirement was estimated as 470 $\mathrm{mm}$, with peak weekly requirements of about $200 \mathrm{I} \mathrm{tree}^{-1}\left(1250\right.$ trees ha $\left.^{-1}\right)$ while dry bean yields of between 1.5 and $2.7 \mathrm{tha}{ }^{-1}$ was achieved from young trees.

The annual total rainfall in the cocoa growing regions of Nigeria is about $1500 \mathrm{~mm}$ (less than $2000 \mathrm{~mm}$ ). The rainfall distribution pattern is bi-modal from April to July and September to November. There is a short dry period from July to August during which the relative humidity is still high with over cast weather conditions. There is a main dry season from November to February-March. The four to six months of dry weather results in soil water deficit and since irrigation is not part of the farming system, causing seedling mortality (Famuwagun et al., 2017). In bearing plants, the existence of the short dry season during main crop pod filling can affect bean size if it is sufficiently severe. In adult plantings, water deficits result in lower yields and an increase in the level of mirid (capsid) damage. In the rainforest cocoa growing belt of west Africa, fruit trees in plantations (cacao, kola, coffee, citrus species and oil palm) are seldom irrigated especially during the terminal drought situation of the dry season. Few studies had addressed the responses of cacao to dry season irrigation especially, the effects of irrigation on root zone moisture dynamics, tree water use, growth and yield in the premise of unfavourable weather constituted by soil moisture deficit and high temperature stresses of the dry season.

Given the changing environment regimes (soil and weather/climate) and increasing worldwide demand for cocoa, it is important to develop sustainable production systems based on sound agronomic practices such as irrigation to ameliorate the extreme weather conditions (hydrothermal stresses), improve its productivity and extend frontiers of its production to marginal weather and soil conditions. Few studies had addressed these features in tropical trees and very little is known about cacao the responses of cacao to dry season irrigation in the premise of unfavourable weather constituted by soil moisture deficit and high temperature stresses. In addition, information is inadequate on water use of cocoa and dynamics of soil moisture extraction as affected by irrigation regimes. Experiments were designed to examine the effects of regulated dry season irrigation on root zone moisture dynamics tree water use, and bean yield of cacao in a rainforest zone of Nigeria.

\section{Materials And Methods Experimental Site and Conditions}


An experiment was conducted on the Research and Experiment Station of the Department of Crop, Soil and Pest Management, Federal University of Technology Akure, Nigeria. Akure is located in the rainforest zone of south west Nigeria on latitude: $7^{\circ} 18^{1} \mathrm{~N}$, Longitude: $5^{\circ} 8^{1} \mathrm{E}$ and $350 \mathrm{~m}$ abs. Five to six years old fruiting cacao trees which had been previously irrigated during dry season from seedling establishment (April, 2013) till date were used.

The cocoa-growing rainforest belt of southern Nigeria, is characterized by wet and dry season transition, and the seasons have variable weather conditions. The annual rainfall range from 1500 to over $2000 \mathrm{~mm}$ distributed in a bimodal pattern within seven to eight months duration and 3 to 4 months of dry season. The dry season is a terminal drought situation characterized by inadequate rainfall,, soil moisture, high vapour pressure deficit and temperatures stresses and very clear sky (high intensity of solar radiation) (Famuwagun et al., 2017, Charles et al., 2019).In the rainforest cocoa growing belt of west Africa, fruit trees in plantations (cacao, kola, coffee, citrus species and oil palm) are seldom irrigated especially during the terminal drought situation of the dry season

\section{Soil characteristics and moisture determination}

The soil of the site of experiment is sandy-clay-loam with relatively high water holding capacity. Available soil water in the upper $0.60 \mathrm{~m}$ of the soil depth is $187 \mathrm{~mm}$. the percent and volumetric soil water contents at field capacity and permanent wilting point are 21 and $10 \%$ respectively. Mean bulk density was

$1.25 \mathrm{~g} \mathrm{~cm}^{-3}$. The soil at the site of the experiments was Soil samples were taken and subjected to routine Laboratry analysis for physical (textural class, bulk density, water holding capacity) and chemical (organic matter, N, P, K Ca, Mg, CEC, electrical conductivity) properties using standard procedures.

Soil samples were taken using soil Auger for water content measurement within the top soil layer $(0-30 \mathrm{~cm})$ by gravimetric method. Core samples were taken for bulk density and porosity measurement. Soil moisture content would attain field capacity in two days since the soil is sandy clay to silty clay loam (Agele et al., 2014). The samples were taken two days after and just before the next irrigation. The difference in moisture content between the two sampling periods was taken to be the moisture used. That is, the evapotranspiration by the crop for that period. Since it was assumed that drainage was negligible (no drainage), the moisture change was principally attributed to evapotranspiration. Soil moisture depletion (SWD) was obtained from the differences in soil moisture contents (changes in soil moisture contents:(DS) measured between two measurement period. Soil moisture contents were determined weekly at 20 $\mathrm{cm}$ depths from soil samples taken with augers and core samplers.

\section{Irrigation Strategies}

Cacao trees were drip-irrigated based on levels of cumulative pan evaporation. Irrigation treatments were based on the restoration of cumulative Pan evaporation (EPan) using variable Pan coefficients (Kcp) of 100, 70 and 50 \% (Allen et al., 1998; Sezen et al., 2010; Agele et al., 2014). The Pan coefficients $(100,70$ and $50 \% \mathrm{Kcp}$; the relative water deficit of 0, 0.3 and 0.5$)$ indicated zero, high and low water stress conditions and respectively.

Irrigation amount was calculated using Pan evaporation and Pan coefficients (Kcp1: 1.0; Kcp2: 0.7, and Kcp3: 0.5) according to Doorenbos and Pruitt (1975) and Allen et al. (1998) as:

$\mathrm{Ir}=\mathrm{A} *$ EPan *Kcp...............6

where Ir is the amount of applied irrigation water $(\mathrm{mm}), \mathrm{A}$ is the plot area, EPan is the cumulative evaporation at irrigation interval (mm) and Kcp is the plantpan coefficient.

Irrigation treatments were coded as EPan *100 Kcp (IrT1), EPan * $70 \% \mathrm{Kcp}(\mathrm{IrT} 2)$ and EPan *50 \% Kcp (IrT3) while irrigation was fixed at 5 days-interval for the three irrigation treatments. Irrigation treatment IrT3 had the maximum water deficit which was used to determine stressed baseline while IrT1 suggest adequate irrigation to meet full crop water requirements (the non-crop water stress baseline). Irrigation water was applied using gravity-drip irrigation system at $4.8,6.8$ and $9.6 \mathrm{l} /$ tree/day at each irrigation via point source emitters of $2 \mathrm{l} / \mathrm{h}$ discharge rate which were installed on laterals per row of cacao tree spaced at $3 \times 3 \mathrm{~m}$. One drip lateral served each plant row and an inflow meter was installed at the control unit to measure total flow distributed to all replications in each treatment. Irrigation buckets were suspended on $3.5 \mathrm{~m}$ high tank stands to provide the required hydraulic heads (Agele et al., 2014, Charles et al., 2019).

Total amount (volume) of irrigation water applied per treatment was calculated using equation:

$V=P * A * E P a n * K c p \quad \ldots \ldots \ldots . . .7$

where, $\mathrm{V}$, is the volume of irrigation water (L); P, wetting percentage (taken as $100 \%$ for row crops); $\mathrm{A}$, is plot area ( $\left.\mathrm{m}^{2}\right)$; EPan is the amount of cumulative evaporation for the irrigation interval (5-days) and Kcp Pan coefficients (1.0, 0.7 and 0.5). This corresponded to $7.14 \mathrm{~mm}$ (1.93 I/day), $10.7 \mathrm{~mm}$ (2.90 I/day), $14.28 \mathrm{~mm}(3.86 \mathrm{l} /$ day $)$ for the respective $0.5,0.7$ and $1.0 \mathrm{Kcp}$. In order to attain good plant stand, a pre-treatment total of $135 \mathrm{~mm}$ of irrigation water was applied equally to all treatment plots in several applications, this replenished soil water in the $0.60 \mathrm{~m}$ profile depth to field capacity across treatments. Following the pre-treatments of $4.82 \mathrm{l}$ /day for 5 days, differential irrigation treatments commenced on $13^{\text {th }}$ December , 2017 and was terminated May $9^{\text {th }}$, 2018. The amount of water applied per irrigation and seasonal irrigation amount varied from a maximum of $4.82 \mathrm{l} / \mathrm{day}$ and $127500 \mathrm{~mm}\left(\mathrm{DI}_{1}\right.$ level) to a minimum of $1.93 \mathrm{l} /$ day and $20400 \mathrm{~mm}$ ( $\mathrm{DI}_{4}$ level). Irrigations continued until one week before the final harvest.

Actual crop evapotranspiration (ETc) of cacao under the irrigation amounts was calculated with the water balance equation (Equation 1) (Agele et al., 2014)

$E T+I+P+\Delta S-D p-R f$ 
where, ET, is actual crop evapotranspiration $(\mathrm{mm})$; I, the amount of irrigation water applied $(\mathrm{mm})$; P the precipitation (mm); $\Delta S W$, changes in the soil water content $(\mathrm{mm})$; Dp, the deep percolation $(\mathrm{mm})$; Rf, amount of runoff $(\mathrm{mm})$. Since the amount of irrigation water was controlled, deep percolation and run off were assumed to be negligible. Daily crop evapotranspiration was estimated using the pan evaporation data, pan factor and crop coefficient (Doorenbos and Pruitt, 1977, Agele et al., 2014). Data for Pan evaporation (EPan) used for the experiment were obtained from measurements with Class-A Pan (121 cm in diameter and $25.5 \mathrm{~cm}$ in depth) from the Meteorological Station, Department of Meteorology \& Climate Science, FUTA) located near the plots.

Deep percolation was considered as zero because there was no high underground water problem in the area. If available water in the root zone ( $0-90 \mathrm{~cm})$ and total applied water amount by irrigation were above the field capacity, it would be assumed that water amount above field capacity leaked into the deeper soil zones and was called deep percolation (Dp: available total water amount at 0-90 cm soil depth before irrigation + applied irrigation water field capacity) (Doorenbos and Pruitt, 1977). Total water requirement (WR) was determined using the relation:

$W R=A \times B \times C \times D \times E$ . .9

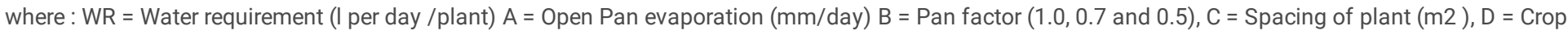
factor (factor depends on plant growth, value for fully grown cacao $=1.13$ but for cacao in the early fruiting stage, 0.83 was adopted). Water requirements (WR) were 9.63, 6.75 and 4.8 I/plant/day for the respective IrT1, IrT2 and IrT3 irrigation treatments.

Irrigation water requirement is determined using average season wise pan evaporation data for the area. The total water requirement (TWR) of the farm plot was obtained using the relation. Therefore, the total water requirement (TWR) of the farm plot is:

TWR $=$ WR $\times$ No. of Plants. 10

Maximum allowable deficit (MAD) for cacao (50\% of available water storage capacity of the soil (AWC) Gross irrigation requirement (GIR) of an orchard or vineyard, the computed ETc, which is considered as the net irrigation requirement (NIR), should be divided by the application efficiency (AE).

$\mathrm{GIR}=\mathrm{NWR} / \mathrm{AE}$ .11

Yield and crop water use were deployed to evaluate appropriate the efficiencies of irrigation management practices among the different irrigation strategies adopted.

\section{Orchard water use efficiencies}

Water productivity (Irrigation water use efficiency (IWUE) and crop water use efficiency (WUE) was determined based on the methods of Sezen et al. (2010) and Agele et al. (2014) as:.

IWUE = Biomass weight $(\mathrm{Y}) /$ total irrigation water applied $(\mathrm{Ir}) \ldots \ldots \ldots . .12$

WUE $($ crop) $=$ Biomass weight $(\mathrm{Y}) /$ Cumulative seasonal ETc. 13

where IWUE is the irrigation water use efficiency (t.ha ${ }^{1} \mathrm{~mm}$ ), EY is the economical yield (t.ha ${ }^{1}$ ), Ir is the amount of applied irrigation water (mm).

Cacao water requirement was determined using FAO-56 single and dual crop coefficient models approach. The aim was to analyze the capacity of the FAO-56 single and dual crop coefficient models to assess cacao evapotranspiration and water requirements (estimating adequacy of irrigation amount for cacao) . The FAO-56 dual crop coefficient approach (Allen et al., 1998) describes the relationship between crop evapotranspiration (ETc) and reference evapotranspiration (ETO) by separating the single Kc into the basal crop ( Kcb) and soil water evaporation (Ke) coefficients, while in the FAO-56 single crop coefficient approach, the effect of both crop transpiration and soil evaporation are integrated into a single crop coefficient (Kc).Cacao orchard irrigation was scheduled from transpiration and evaporation coefficients (Kcb, Ke). FAO I\&D No. 56 publication offers opportunity for differentiating E from Tr by using a dual crop coefficient approach, according to the equation:

$\mathrm{ETc}=(\mathrm{Kcb}+\mathrm{Ke}) \mathrm{ETo}$ . .14

where $\mathrm{Kcb}$ is a transpiration coefficient and Ke is soil evaporation coefficient.

$\mathrm{Kcb}$ is basal crop coefficient $(\mathrm{kcb}=\mathrm{ETc} / \mathrm{ETo})$

$\mathrm{Kc}=\mathrm{kcb}+\mathrm{ke}$. 15 ,

and then,

$\mathrm{ETc}=(\mathrm{kcb}+\mathrm{ke}) \mathrm{ETo}$ . .16

\section{Size of cacao canopies}

Tree canopies may be characterized using two parameters: canopy volume ( $\mathrm{m} 3$ of tree volume/m2 of ground surface) and leaf area density ( $\mathrm{m} 2$ of leaf area /m3 of tree volume). Tree canopy can be measured with a measuring rod once the tree shape has been approximated as a sphere, an ellipsoid, or a truncated 
inverted cone. As an alternative to the measurements or calculations of the radiation actually intercepted by the tree, a simple parameter that is easy to determine is the degree of ground cover. The ground cover (normally expressed in percentage) is obtained by measuring the shaded area outlined from the horizontal projection of the tree canopy

The ground cover (normally expressed in percentage) was obtained by measuring the shaded area outlined from the horizontal projection of the tree canopy

$\mathrm{A}=\frac{d 4^{2}}{4}\left(\mathrm{~m}^{2}\right)$ 17

$\mathrm{d} 4=$ diameter of shaded area by cacao canopy $(2 \mathrm{~m}), \mathrm{A}$ is per cent ground cover by cacao canopy; Tree spacing is $3 \times 3 \mathrm{~m}\left(9 \mathrm{~m}^{2}\right)$; $\mathrm{d} 1$ (areal canopy area), d2 (height bt d1 and d3); d3 (projection of canopy area on ground, d1 > d3).

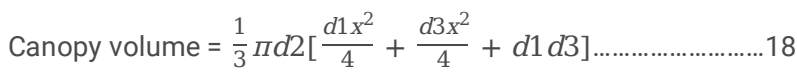

\section{Soil surface evaporation as affected by irrigation}

Soil evaporation (non-wetted surface;Edz) Soil surface outside the emitter wetting) and surface evaporation from the soil wetted by the emitters (emitter wetted zone;EWz)

The equations derived from method of Orgaz et al. (2006) which was adapted for estimating the average monthly value of Ewz and Wdz

Evaporation (EDz) from soil not wetted by emitters (EDz)

$\mathrm{Edz}=\mathrm{Ks}$, e ETo (mm/day) 19

Where $\mathrm{G}$ is ground cover fraction of tree canopy, is monthly rainfall amount, wz is fraction of soil surface wetted by drip emitters $(\mathrm{ETo}=\mathrm{reference} \mathrm{ET})$. EWz of 0.6 ETo for dense crop cover/plant density; EWz is the of soil surface kept wet by emitters, and Cover crop coefficient varies from 0.25 to 0.8

Evaporation (EDz) from soil not wetted by emitters (EDz)

$E d z=K s$, e $E T o(m m / d a y)$ .20

Where $\mathrm{G}$ is ground cover fraction of tree canopy, is monthly rainfall amount, wz is fraction of soil surface wetted by drip emitters $(\mathrm{ETo}=\mathrm{reference} \mathrm{ET})$

Cover crops/weed cover transpiration (Tr $\operatorname{Tr})$.

Weed cover up to $2 \mathrm{~m}$ in a $3 \mathrm{~m}$ row spacing

\section{Transpiration (Tr) of cacao orchard}

Cacao is deciduous (partly evergreen in some cases), its crop coefficient (Kc) and Tr were determined using the methods of (...........) and Orgaz et al. (2006).

$\mathrm{Kc}, \operatorname{Tr}=\left(\mathrm{QdF}_{1}\right) \mathrm{F}_{2}$

$\mathrm{Qd}=1-e^{-k e x t V u}$ .22

where $\mathrm{K}$ ext is radiation extinction coefficient.

Kext $=0.52+0.00079 \mathrm{dp}-0.76 \mathrm{e}-1.25 \mathrm{DAF} .$. .23

$\mathrm{DAF}=2-0.53(\mathrm{Vu}-0.5)$ .24

where DAF must be > 2); $\mathrm{Vu}=\mathrm{Vo}(\mathrm{dp} / 10000), \mathrm{Vo}=1 / 6 \mathrm{DD}^{2} \mathrm{H}$

$\mathrm{E}$ (exponent $=2.718), \mathrm{H}$ (height of canopy; $\mathrm{m}$ ); $\mathrm{D}$ is average canopy diameter, $\mathrm{m}$ ); Vo is canopy volume ; $\mathrm{m}^{3} /$ tree); Vu is canopy volume as amount on ground cover; $\left.\mathrm{m}^{3} / \mathrm{m}^{2}\right)$; DAF is leaf area density; dp is tree density; number/ha), $\mathrm{Fi}=0.07$ for tree density greater than 300 trees/ha), $\mathrm{F} 2$ is monthly coefficient of $\mathrm{Tr}$ which is about 0.7 to 1.0 from wet to dry seasons

$Q d=1-e^{-k e x t V u}$

$\mathrm{Kc}, \operatorname{Tr}=\left(\mathrm{QdF}_{1}\right) \mathrm{F}_{2}$ .25 
$\mathrm{Kc}$, t is empirical coefficient relating the ET of an orchard of incomplete cover to a mature orchard of full canopy cover. In addition, Kr,t relates to horizontal projection of tree shade/canopy (ground cover per cent; Orgaz et al., 2006), and Kr,t is about 0 to $70 \%$ of $\mathrm{G}$

\section{Cacao orchard Transpiration (Tr) was determined as:}

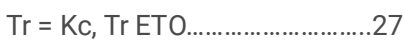

where $\mathrm{Kc}$, Tr is transpiration coefficient which varies bt 0.75 to 1.0 seasonally until leaf senescence onset for a fully wetted orchards (sufficient soil moisture situation) (Kc, Tr decrease at senescence and recovers at the onset of rainfall.

\section{Results And Discussion Weather conditions during period of study}

The late (minor) rainy season (mid August to December) is characterized by high cloud overcast (overcast sky), low air temperatures and higher relative humidity compared with the major rainy season (April to mid August) and the dry season (Fig. 1). On the average, the rainy season had higher mean relative humidity averaged $(71 \%)$ and lower air temperatures $\left(32.8^{\circ} \mathrm{C}\right)$ compared with the dry season (December to March). Also, higher air temperature and VPD and lower relative humidity were found for the unshaded open sun cacao compared with the shaded plants.

A low pressure gravity-drip system was deployed to deliver water to cacao rootzone which alleviated moisture stress during the dry season.Across sampling dates, different amounts of irrigation water were applied based on cumulative Pan evaporation (EPan)*Pan coefficients for the respective irrigation treatments IrT1 (EPan.kc:1.0), IrT2 (EPan.Kc:0.7) and IrT3 (EPan.Kc: 0.5). Irrigation amounts on monthly averages were 1009.88, 706.91 and $504.94 \mathrm{~mm}$ while seasonal totals were 2116.5, 8482.95 and 6059.25 mm for IrT1; IrT2 and IrT3 treatments. Well irrigated treatment (IrT1, EPan.kc:1.0) had highest amount delivered and lowest by IrT3 (EPan.kc:0.5) (Fig. 2). The deficit irrigations (IrT2 and IrT3) delivered 79 and 68\% respectively water to cacao rootzone compared with the well irrigated condition. Peak and significantly higher values of irrigation amount were delivered at DOY 45, 60, 75 and 90, periods which coincided with highest EPan values ( $>5 \mathrm{~mm} /$ day).

The irrigation treatments (IrT1, IrT2 and IrT3) affected soil moisture contents within cacao root zone. Soil moisture contents adequately reflected the irrigation water delivered across measurement dates (Fig. 3). Highest soil moisture contents were obtained for well irrigated (IrT1) and lowest for deficit irrigation (IrT3) treatment. For the respective deficit irrigation treatments (IrT2 and IrT3: 0.7 and 0.5 EPan coefficients), average soil moisture contents were 61,48 and $42 \%$ for IrT1, IrT2 and IrT3 irrigation treatments (Fig. 3). Highest soil moisture contents and crop evapotranspiration (ETc) were obtained from well irrigated plots (IrT1: EPan*kcp (1.0 (9.6 I/tree/day) followed by IrT2 (EPan*kcp (0.7) (6.8 I/tree/day) and lowest for IrT3 EPan*kcp (0.5) (4.8 I/tree/day). The deficit irrigation treatments (IrT2 and IrT3) had lower soil moisture contents (14.7 and $11.8 \%$ ) which equated to 30 and $50 \%$ water savings.

Declines in soil moisture contents were obtained from DOY 345 to DOY 60 , followed by increasing trends in soil moisture from DOY 75 till end of measurement (DOY 150). Declining trends in the values of soil moisture contents may be attributed to the increasing intensities in climatic demand (high vapour pressure deficits). Unfavourable weather of high temperatures and soil evaporation and low atmospheric humidity would enhance soil moisture depletion thus the low soil moisture status (Agele et al., 2011, Agele 2021). Increases in moisture were observed from DOY 75 till end of measurement (DOY 150) can be attributed to rainfall received following its commencement (Mid March). In general, the observed trends in the status of rootzone moisture is attributable to the prevailing weather conditions denoted by increasing intensities of climatic demand (vpd) and temperatures during periods (DOY 345 to 60 ) of experiment.

\section{Cycle of soil water before and after irrigation}

Soil water contents were measured using soil samples within the $0-20 \mathrm{~cm}$ soil profile depth before and one day after each irrigation. Soil moisture contents across measurement days ranged between wilting point $(140 \mathrm{~mm}$ ) before irrigation and field capacity (260 mm) after irrigation (data not shown). For the low and high water stress conditions (IrT2 and IrT3), soil moisture was often close to wilting point before each irrigation. For the deficit irrigation treatments (IrT2 and IrT3: 0.7 and 0.5 Pan coefficients), available water fell below 50\% more often than not during the period of study. Because much more water was applied under high Pan coefficients (Kcp 1.0), soil moisture contents of well watered treatments (IrT1) was higher compared with deficit irrigation (IrT2 (0.7 Kcp: and IrT3 $0.5 \mathrm{Kcp}$ ) treatments. The well watered treatment (IrT1), most times, maintained soil moisture within field capacity range.

In general, based on the values of soil moisture, the stored water within crop rootzone profile was used up between irrigation cycles. This is attributable to the intensities of climatic stress (high temperatures and vapour pressure deficits) which presumably enhanced soil evaporation and the rapid depletion of water stored in the soil profile. Soil moisture content immediately following irrigation gradually decreased towards next irrigation event, this situation confirms the inability of soil moisture reserve to satisfy cacao water demand during the dry season which was consistent with earlier reports of Famuwagun et al. (2017) and Charles et al. (2019).

Soil moisture depletions over two measurement days were deployed to determine cacao water use (ETc). Cacao water use (ETc) differed across measurement dates and irrigation treatments (Fig. 4a). Average cacao evapotranspiration (ETc) were 139, 97and 63 mm/day for the respective IrT1 (IrT1 (Kc:1.0), IrT2 (Kc 0.7 ) and IrT3 (Kc 0.5). Cacao evapotranspiration (ETc) for the deficit irrigation treatments (IrT2: 0.7 and IrT3:0.5 EPan coefficients) were averagely 45 and $70 \%$ less compared to values to adequate irrigation (IrT1) treatment which signified soil moisture deficit stress. Peak ETc values were obtained at DOY 45,60 and

Page $7 / 13$ 
75 possibly due to high EPan (> $5 \mathrm{~mm} /$ day), lowest for DOY 120 and 135 with increases afterwards. The increases in cacao water use (ETc) from DOY 135 afterwards are attributable the commencement of rainfall and associated replenishment of soil moisture, lowering of temperatures (air and soil) and high atmospheric humidity (declining atmospheric demand). The well watered treatment (IrT1) had highest ETc and the more deficit irrigation (IrT3) had least cacao water use (Fig. 4a). The mean ETc across measurement dates were 5.07, 3.55 and $2.63 \mathrm{~mm} /$ day for IrT1, IrT2 and IrT3 irrigation treatments for the period of experiment (December to May).

In addition to single crop coefficient ( $k c=1.31)$, cacao water requirement (ETc) was also computed using the dual (kr t: 1.04) crop coefficient (Fig. 4b). Means of cacao water use for dual crop coefficient across measurement dates were 5.2, 3.7 and $2.8 \mathrm{~mm} /$ day for IrT1, IrT2 and IrT3 irrigation treatments for the period of experiment (December to May). The time course of cacao water use estimated using both the single and dual crop coefficients are presented in Fig. 5a, b and c. Results showed similar trends in cacao ETc for both methods and irrigation treatments while values were higher for the dual coefficient compared with the single kc (Fig. 5a, b and c). The decreasing order of ETc for single kc and dual kc were IrT1 > IrT2 > IrT3. Crop evapotraspiration (ETc) increased with increases in the volume of irrigation water applied, this modified values of ETc obtained for both the single and dual kc approaches.

The FAO-56 dual crop coefficient approach (Allen et al., 1998) which describes the relationship between crop evapotranspiration (ETc) and reference evapotranspiration (ETo), separates the crop coefficient (Kc) into the basal crop (Kcb) and soil water evaporation (Ke) coefficients. In the single crop coefficient approach, the effect of both crop transpiration and soil evaporation are integrated into a single crop coefficient (Kc) while in the dual coefficient approach, a daily basal crop coefficient (representing plant transpiration: $\mathrm{Kcb}$ ) and daily soil evaporation coefficient $(\mathrm{Ke})$ in the form of $\mathrm{Kc}=\mathrm{Kcb}+\mathrm{Ke}$ ). However, crop evapotranspiration (ETc) estimation is more accurate by dual crop coefficient approach than the single crop coefficient approach, the dual crop coefficient approach uses more parameters and take soil management practices and crop characteristics into consideration (Allen et al., 1998).

The magnitudes of cacao ETc (single and dual crop coefficients obtained from the respective irrigation treatments followed from the irrigation water delivered (Fig. 5a, b and c). The irrigation regimes affected soil moisture contents and thus, its availability to meet crop water use. The values of cacao water use obtained from the respective irrigation treatments would have followed from the irrigation water delivered. Irrigation under well watered treatment increased tree water use and soil moisture status compared with deficit irrigation treatments (IrT2 and IRT3) which is consistent with reports on citrus by Yang et al. (2002). The magnitude of cacao ETc obtained in this study are within the range of those reported in literatures (Carr, 2011). Cacao water use (ETc) values ranging from 3 to $5 \mathrm{~mm} /$ day during rains and less than $2 \mathrm{~mm} /$ day in the dry season has been reported under irrigation regime of 10 litre/tree/day (Penman, 1948), Kohler et al. (2010) obtained cacao ETc of $2 \mathrm{~mm} /$ day and Moset et al (2010) obtained $1.3-1.5 \mathrm{~mm} /$ day in Indonesia. Cacao transpiration average of $1.31 \mathrm{~mm} \mathrm{~d}^{-1}$ (about 10 litres per tree per day) and ETc computed with a Penman potential ETo of $3-5 \mathrm{~mm} \mathrm{~d}^{-1}$ have been reported (Moser et al., 2010 ). This value equates to crop factor (Kc) of about 0.3 (Penman, 1948, Moser et al., 2010). Field data (based on the sap flow method) suggest ETc rates of less than 2 $\mathrm{mm}$ /day for cocoa crop with a complete canopy, this appear to be low compared with potential ETo estimate of 3-5 mm d $\mathrm{d}^{-1}$ using Penman equation (Penman, 1948).

The ETc/EPan ratio denotes the proportion of climatic water demand satisfiable by crop water use (ETc). Among the irrigation treatments. The proportions of Pan evaporation (EPan) to cacao water use (ETC) denoted as ETc/EPan ratio, differed across measurement dates and irrigation treatments. The means of ETC/EPan ratios across measurement dates were 1.016, 0.714 and 0.492 for the respective IrT1, IrT2 and IrT3 treatments (Fig. 6a). ETc/EPan curves were similar but the ratios ranged from 1.16 to 0.50 which indicated that both climatic demand (EPan) and cacao water consumption (ETc) were high during the dry season at the site of study. Although a weak relationship, linear regression equation was fitted to the $E T c / E P a n$ trends as: $\left.Y=0.011 x+0.94, R^{2}=0.32\right)$. The ratio of water use $(\mathrm{ETC})$ to irrigation water applied denotes the proportion of irrigation water applied used for crop evapotranspiration. Trends of ETc to irrigation were similar among irrigation treatments and measurement dates but values differed among irrigation treatments (Fig. $6 \mathrm{~b}$ ). The mean values were $1.016,0.714$ and 0.492 for the respective IrT1, IrT2 and IrT3 treatments (Fig. $6 \mathrm{~b}$ ). Generally, the ratios ranged from 1.13 to $0.27,0.79$ to 0.19 and 0.57 to 0.14 which indicated differences in the ability of irrigation water applied to satisfy climatic demand (EPan) driven trends of cacao water consumption (ETC). When soil water is readily available to a crop, the rate of water evaporation from an Evaporation Pan is proportional to the rate of crop water use (Doorenbos and Kassam, 1979, Allen et al., 1998). Doorenbos and Kassam (1979) found positive linear and significant logarithmic correlation (P< 0.01$)$ between ETc and EPan while Smajstrla et al. (2000) obtained significant logarithmic correlation $(P<0.01)$ between ETc and EPan. These reports confirmed the established close relationship between plant water consumption and Pan evaporation.

\section{Soil evaporation from cacao orchard}

The ETc from an orchard is more complex. In addition to tree Tr, there could be Tr losses from cover crop or from weeds, and there are E losses from the soil. Under irrigation conditions, there are two $\mathrm{E}$ components that may differ in their rates: one is the $\mathrm{E}$ from the soil areas wetted by the emitters, and the other is the $E$ from the rest of the soil surface which is only wetted by rainfall.

Soil evaporation was respectively estimated for the wetted zone (Edz) and the non-wetted zone (Ewz) during the period of experiment. The mean values for soil evaporation for the wetted (Edz) were 5.65, 2.82 and $0.19 \mathrm{~mm} /$ month for the respective IrT1, IrT2 and IrT3 treatments. The seasonal totals soil evaporation for the wetted (Edz) and the non-wetted ( Ewz) zones were 234.29 and $33.94 \mathrm{~mm}$ respectively. Based on the cumulative seasonal totals, soil evaporation for the wetted zone (Edz) was averagely 7 times compared with the non-wetted zone( Ewz) (Fig. 7).

Irrigation replenished soil moisture depletion while cacao canopy produced cover to soil and a more favourable microclimate around the canopy spread. This is appear to explain the magnitudes of soil evaporation from the wetted (Edz) and the non-wetted (Ewz) zones within cacao field (Tombesia et al., 2018). Studies also indicated that the conditions at the soil surface due to (i) the percentage of soil surface wetted via irrigation, (ii) the irrigation intervals and (iii) the soil exposure to light determine the dynamics of Tr and Es in orchards (Bonachela, 2001, Tombesia et al., 2018). In this study, drip irrigation was deployed 
to replenish moisture depletion from cacao root zone. There were spatial variations in the degree of wetting within the orchard; some areas are frequently wetted by the emitters while the rest of the soil surface remains dry in the absence of rainfall. The drip lines were placed near the trees while the wetted areas are shaded by the cacao canopy. The effects of orchard canopy and drip irrigation appeared adequate to alleviate radiation-limited soil water evaporation (E). Measurements and models suggest that $E$ from the soil surface in orchards, which are wetted frequently (every 1-2 days) by emitters is equivalent to about 60 percent of the ETo from the wet areas (Bonachela, 2001, Garcia-Tegera et al., 2017). As a first approximation, the quantification of E from the wetted spots in a drip-irrigated orchard can be made using a semi-empirical model of Bonachela (2001) of the relation:

$\mathrm{Es}=0.6 \mathrm{ETO}$. . .28

Total pod and bean yields were highest for $\operatorname{IrT1}\left(35.4\right.$ and 2.29 t.ha $^{-1}$ ) followed by IrT2 (22.1 and 1.37 t.ha ${ }^{-1}$ ) and lowest (10.3 and 1.03 t ha ${ }^{-1}$ ) for $\operatorname{IrT3}^{\text {B Bean }}$ yields decreased by 60 and $40 \%$ under IrT3 and IrT2 compared with IrT1 (Table 1). Deficit irrigations however produced 30 and $50 \%$ water savings compared to well watered treatment (IrT1). Water productivity was affected by irrigation regimes. Water use efficiencies values ranged between 0.3 and $0.04 \mathrm{t} / \mathrm{mm}$ for Y/ETc and 0.16 to $0.19 \mathrm{~kg} / \mathrm{mm}$ for Y/Irrigation respectively (Table 1). The yields of pods and beans were significantly higher in IrT1 treatments compared with IrT2 while they were lowest significantly for IrT3. However, Carr (2011) and Charles et al. (2019) had reported that fruit yield does not only depend on irrigation amount but a function of other management practices adopted and soil properties such as infiltration rate, and water holding capacity. Irrigation effect was profound both on number and weight of pods and beans in cacao. Evaluation of irrigation amount and frequency should not only consider fruit yield and yield components, but also consider WUE (García-Tejero et al., 2011, Charles et al., 2019). Other studies have reported irrigation effects on biomass, pod and bean yields of cacao. Dicbalis et al (2010) working in Australia examined effects of seasonal irrigation requirement of $470 \mathrm{~mm}$ and $200 \mathrm{l} /$ tree for weekly irrigation and obtained resultant bean yields of $1.5-2.7 \mathrm{t} / \mathrm{ha}$. Based on field trials by Diczbalis et al. (2010), the annual irrigation requirement was estimated as $470 \mathrm{~mm}$, with peak weekly requirements of about $200 \mathrm{I} \mathrm{tree^{-1 }}\left(1250\right.$ trees ha $\left.^{-1}\right)$ while bean yields of between 1.5 and $2.7 \mathrm{tha}{ }^{-1}$ were obtained as achieved from young trees.

Table 1

Summary of measured soil and cacao variables

\begin{tabular}{|c|c|c|c|c|c|c|c|c|c|c|c|c|c|c|}
\hline Imigation & $\begin{array}{l}\text { Seasonal } \\
\text { irrigation }\end{array}$ & $\begin{array}{l}\text { Scm } \\
(\%)\end{array}$ & $\begin{array}{l}\text { ETc } \\
\text { Single } \\
\text { (kc:1.13) }\end{array}$ & $\begin{array}{l}\text { ETc } \\
\text { Dual } \\
\text { (krt: } \\
\text { 1.04) }\end{array}$ & $\begin{array}{l}\text { ETc/ } \\
\text { EPan } \\
\text { ratio }\end{array}$ & $\begin{array}{l}\text { Seasonal } \\
\text { ETc }\end{array}$ & $\begin{array}{l}\text { No.Pods/ } \\
\text { plant }\end{array}$ & $\begin{array}{l}\text { Pod } \\
\text { wgt } \\
\text { /plant } \\
(\mathrm{kg})\end{array}$ & $\begin{array}{l}\text { No. } \\
\text { Beans/ } \\
\text { plant }\end{array}$ & $\begin{array}{l}\text { Bean } \\
\text { Wgt/ } \\
\text { Plant } \\
\text { (g) }\end{array}$ & $\begin{array}{l}\text { Bean } \\
\text { wgt } \\
(\mathrm{kg} / \mathrm{ha})\end{array}$ & $\begin{array}{l}\text { WUE } \\
\text { (IIr) }\end{array}$ & $\begin{array}{l}\text { WUE } \\
(E T C)\end{array}$ & $E W z$ \\
\hline $\operatorname{IrT1}$ & 33858.2 & 21.4 & 5.07 & 5.2 & 0.92 & 139.1 & 15.4 & 4429 & 114 & 396.5 & $\begin{array}{l}4.41 \\
440511.5\end{array}$ & 0.0117 & 0.032 & 5.65 \\
\hline IrT2 & 32705.3 & 17.3 & 3.55 & 3.7 & 0.73 & 97.3 & 12.3 & 3125 & 102 & 334.3 & $\begin{array}{l}3.72 \\
371407.3\end{array}$ & 0.0142 & 0.043 & 2.82 \\
\hline IrT3 & 16929.4 & 14.4 & 2.63 & 2.8 & 0.56 & 62.7 & 9.8 & 2673 & 91 & 308.1 & $\begin{array}{l}3.42 \\
342299.1\end{array}$ & 0.0182 & 0.055 & 0.19 \\
\hline $\begin{array}{l}\angle S D \\
(0.05)\end{array}$ & & 4.1 & 1.8 & 1.6 & 0.21 & 17.3 & 2.7 & 134.5 & 5.4 & 23.8 & 0.25 & 0.003 & 0.005 & 1.33 \\
\hline
\end{tabular}

Cocoa is cultivated as a rainfed crop but sensitive to weather extremes of low rainfall, soil moisture deficit and high temperature stresses had been variously reported in the literature (Opeke, 2006, Zuidema et al., 2005, Daymond and Hadley, 2004, Daymond et al., 2002, Charles et al., 2019). Global warming (including 1.5 to $2{ }^{\circ} \mathrm{C}$ ), drought and other climate-related disasters are tied to the changing climate, extreme and variability of the weather (IPCC, 2014 , UFCCC, 2004). These situations would drive decreases of regional precipitation and increase in evapotranspiration driven (Sheffield et al., 2012, Tombesia et al., 2018, Agele, 2021). These conditions may enhance yield decreases associated with enhanced heat and water stress under present and future climate conditions. The climate models of the rainforest of Nigeria have been variously constructed (Akinseye et al., 2017). The results indicate that the projected climatic changes will exacerbate soil moisture and thermal stresses with implications for crop performance (Agele et al., 2021). As precipitation becomes more variable and unpredictable in addition to the expected increased warming due to changing climate, development of water-saving management practices for sustainable agriculture now and in the future is envisaged (Sheffield et al., 2012, Tombesia et al., 2018, Agele et al., 2021).

Establishing the optimal irrigation scheduling is important in the development of water-saving practices for sustainable cacao production and climate stress alleviation in the wake of the hydrothermal (extreme heat and water deficits) stresses envisage under future climate.

The site of study in the rainforest zone of Nigeria is characterized by bi-modal rainfall pattern and the wet-dry season transition. The rainfall distribution pattern is bi-modal from April to July and September to November. The dry season which span December of a year to April of the other, is a terminal drought situation characterized by inadequate rainfall,, soil moisture deficit, high vapour pressure deficit and temperatures and very clear sky (high intensity of solar radiation (Agele et al., 2016, Famuwagun et al., 2017, Charles et al., 2019). Such unfavorable weather condition will enhance hydrothermal stresses, evapotranspiration, leaf senescence, branch and twig die-back and even tree mortality (Famuwagun et al., 2017, Charles et al., 2019). Accurate estimates of crop water requirements plays an important role in the improvement of crop productivity and irrigation performance. This issue is particularly relevant considering the need for intensification of irrigation agriculture and increased water scarcity in several regions of the world.

\section{Conclusions}


This study evaluated the dynamics of root zone moisture and cacao water use (ETc) under variable irrigation regimes using EPan and variable Pan coefficients (Kcp: 1, 0.7 and 0.5) using a low pressure gravity-drip irrigation system. Variable Pan coefficients were evaluated for irrigation scheduling for cacao in the rainforest zone of Nigeria. A secondary innovation, was the determination of cacao water and irrigation requirements. Results showed that full irrigation treatment (IrT1:EPan *Kcp = 1.0) produced highest replenishment of depleted moisture from root zone and maximum cacao water use, LAI, pod and bean yields. The lower soil moisture status and water use (ETC) under reduced irrigation treatments (IrT2 and IrT3) were associated with lower pod and bean yields. Although, full irrigation treatment (IrT1: EPan*Kc 100) enhanced soil moisture storage, cacao ETc, pod and bean yields, the deficit irrigation treatments (IrT2: $0.7 \mathrm{Kcp}$ and IrT3: $0.5 \mathrm{Kcp}$ ) were accompanied by 30 and 50 water savings. Soil evaporation from the wetted (emitter zones: Ez) represented good fraction of seasonal orchard evapotranspiration (ET), values ranged from 15-31\% which constituted $31 \%$ ground cover or fraction of soil surface wetted by the emitters). The deficit irrigation strategies imposed mild to severe water stress of cacao, the water saving advantage can be scaled up as irrigation strategy for dry season irrigation. The study established cacao water use, and irrigation requirement, cacao water use (ETc) and suitable Pan coefficients for scheduling irrigation for cacao. Full irrigation involving high Kc (EPan*1.0) applied at $9.6 \mathrm{l} /$ tree/day will be needed to replenish soil water depletion to satisfy crop consumptive water use (ETc : transpiration and soil evaporation components) during the terminal drought situation of the dry season in the rainforest zone of Nigeria. Findings from this study would find use for irrigation decision making for cacao cultivation in the rainforest of the tropics, which is of relevance in the premise of growing environment conditions imposed by the changing climate, extreme and variability of weather. The low pressure gravity-drip irrigation system alleviated climate stress during the dry season and improved cacao performance in a tropical rainforest environment.

\section{References}

1. Agele, S. 2021. Global Warming and Drought, Agriculture, Water Resources, and Food Security: Impacts and Responses from the Tropics. In: Handbook of Climate Change Management. (Leal Filho W., Luetz J., Ayal D. eds.) Springer, Cham. https://doi.org/10.1007/978-3-030-22759-3_183-1

2. Agele, S.O., Iremiren, G.O. \& Ojeniyi, S.O. 2011.Evapotranspiration, water use efficiency and yield of rainfed and irrigated tomato in the dry season in a humid rainforest zone of Nigeria. International Journal of Biology \& Agricultural Sciences 13, 469-476.

3. Agele S. O. Anifowose, AY. and Agbona, A.I. 2014. Irrigation scheduling effects on components of water balance and performance of dry season fadamagrown pepper in an inland-valley ecosystem in a humid tropical environment. International Journal of Plant and Soil Science 4(2): 171-184.

4. Agele, S. Famuwagun, B. \& Ogunleye, A. 2016. Effects of shade on microclimate, canopy characteristics and light integrals in dry season field-grown cocoa (Theobroma cacao L.) seedlings. Journal of Horticulture 11 (1); 47 - 56

5. Akinseye, F.M. Agele, S.O., Traore, P. C. S., Adam, M, and Whitbread, A. M. 2015. Evaluation of the onset and length of growing season to define planting date-'a case study for Mali (West Africa)'Theor Appl Climatol DOI 10.1007/s00704-015-1460-8

6. Allen, R.G.; Pereira, L.S. 2009. Estimating crop coefficients from fraction of ground cover and height. Irrig. Sci. 28, 17-34.

7. Allen, R.G.; Pereira, L.S.; Smith, M.; Raes, D.; Wright, J. 2005. FAO-56 dual crop coefficient method for estimating evaporation from soil and application extensions. J. Irrig. Drain. Eng. 131, 2-13.

8. Allen, R.G.; Pereira, L.S.; Raes, D.; Smith, M. 1998. Crop Evapotranspiration: Guidelines for Computing Crop Water Requirements. FAO Irrigation and Drainage Paper 56; FAO-Food and Agriculture Organization of the United Nations: Rome, Italy. 300 pp.

9. Bonachela, S, Villalobos, SJ \& Fereres, E. 2001. Soil evaporation from drip-irrigated olive orchards. Irrigation Science20, 65-71 https://doi.org/10.1007/s002710000030.

10. Carr, MCV 2011. The water relations and irrigation requirements of cocoa (Theobroma cacao L.): A review. Expl Agric. 47 (4), $653-676$ Cambridge University Press 2011 doi:10.1017/S0014479711000421

11. Charles, E. F., Agele, S. O., Aiyelari, O. P., Famuwagun, I. B., \& Faboade, E. 2020. Shade and Irrigation Effects on Growth, Flowering, Pod Yields and Cacao Tree Survival Following 5 Years of Continuous Dry Season Irrigation. International Journal of Environment and Climate Change, 10(7), 5464. https://doi.org/10.9734/ijecc/2020/v10i730211

12. Daymond AJ and Hadley, P. 2004. The effects of temperature and light integral on early vegetative growth and chlorophyll fluorescence of four contrasting genoypes of cacao (T. cacao) Annals of applied biology, 145, $257-262$.

13. Daymond AJand Hadley, P., Machado, RCR and Ng, E 2002. Canopy charactersitics of contrsasting clones of cocoa (T cacao L.). HortScience 37, 799-801

14. Diczbalis, Y., Lemin, C., Richards, N. and Wicks, C. (2010). Producing Cocoa in Northern Australia. Australian Government, Rural Industries Research and Development Corporation Report 09/092. Dunlop, W. R. (1925). Rainfall correlations in Trinidad. Nature (London)

15. Doorenbos J. and Pruitt, WD. 1977. Crop water Requirements (revised). Food and Agriculture Organization of the United Nations, Irrigation and Drainage Paper 24, Rome. FAO.

16. Ertek, A. 2011. Importance of pan evaporation for irrigation scheduling and proper use of crop-pan coefficient (Kcp), crop coefficient (Kc) and pan coefficient (Kp). African Journal of Agricultural Research Vol. 6(32), pp. 6706-6718. DOI: 10.5897/AJAR11.1522

17. Famuwagun, B., Agele, S. \& Aiyelari, P. 2017. Shade effects on growth and development of cacao following 2 years of continuous dry season irrigation. International Journal of Fruit Science 18(7), 1-24

18. Food and Agriculture Organization (FAO:2012) FAOCLIM: Environment and natural resources service. Working Papers 2012; 5. FAO, Rome

19. Ferreira, MI. (2017).Stress Coefficients for Soil Water Balance Combined with Water Stress Indicators for Irrigation Scheduling of Woody Crops : Horticulturae 2017, 3, 38; doi:10.3390/horticulturae3020038

20. García-Tejera, O., López-Bernal, A. Orgaz, F . FranciscolJ.IVillalobos FJ. 2017.Analysing the combined effect of wetted area and irrigation volume on olive tree transpiration using a SPAC model with a multi-compartment soil solution Irrig Sci DOli10.1007/s00271-017-0549-5 
21. Intergovernmental Panel on Climate Change (IPCC) 2014. Climate Change 2014: Synthesis Report. Contribution of Working Groups I, II and III to the Fifth Assessment Report of the Intergovernmental Panel on Climate Change [Core Writing Team, R.K. Pachauri and L.A. Meyer (eds.)]. IPCC, Geneva,

Switzerland, $151 \mathrm{pp}$.

22. Intergovernmental Panel on Climate Change (IPCC) 2018. Special Report on global warming on $1.5^{\circ} \mathrm{C}$ (SR 14) http://www.ipcc.ch

23. Kohlerlscher, M. Schwendenmann, L. Holscher, D. 2010. Throughfall reduction in a cacao agroforest.: tree water use and soil water budgeting. Agric \& Forest Meteorol. 150. 1079-1089.

24. Locascio, S.J. and A.G. Smajstrla. 1996. Water application scheduling by pan evapo- ration for drip-irrigated tomato. J. Amer. Soc. Hort. $121,63-68$.

25. López-López, M. Espadafor, M. Testi, L Lorite, IJ. Orgaz, F and Elías, F. 2018. "Water use of irrigated almond trees when subjected to water deficits," Agricultural Water Management. 195(C), 84-93.

26. Moser,A., Leuschner, C and Hartel, D. et al.2010. Response of cocoa trees (T cacao) to a 13-month dessication period in Sulawesi, Indonesia. Agroforestry systems 79, 171-187

27. Monteith JL (1973) Principles of environmental physics. Arnold, London, p 291

28. Opeke, L.K., (2006): Tropical commodity crops. Spectrum Books Ltd., Ibadan, Nigeria. 213pp.

29. Orgaz, F, Testi, L. Francisco J. Villalobos, LJ. E. Fereres, E. 2006. Water requirements of olive orchards-II: Determination of crop coefficients for irrigation scheduling Irrigation Science 24(2):77-84. DOI: 10.1007/s00271-005-0012-x

30. Penman HL (1948) Natural evaporation from open water, bare soil and grass. Proc R Soc Lond A193: 120-145

31. Pereira, L.S.; Allen, R.G.; Smith, M.; Raes, D. 2015. Crop evapotranspiration estimation with FAO 56: Past and future. Agric. Water Manag. $147,4-20$.

32. Sezen, S.M., Celikel, G., Yazar, A., Tekin, S., Kapur, B., 2010. Effect ofirrigation management on yield and quality of tomatoes grown indifferent soilless media in a glasshouse. Scientific Research andEssay 5: 41-48.

33. Sheffield, J. Wood, EF. \& Michael L. Roderick, ML 2012 Little change in global drought over the past 60 years Nature volume 491, pages $435-438$

34. Smajstrla, AG. Locascio, SJ, D. P. Weingartner, DP and Hensel, DR. 2000. Subsurface drip irrigation for water table control and potato production. Applied Engineering in Agriculture 16(3):225-229. DOI: 10.13031/2013.5147

35. Testii, L„ \& Villalobos FJ. 2009 New approach for measuring low sap velocities in trees. Agric. For. Meteorol. 149 (3-4), $730-734$.

36. Tombesia,S. Frionia,T.,Ponia, S. and Palliottib, A. 2018. Effect of water stress "memory" on plant behavior during subsequent drought stress. Environmental and Experimental Botany 150 (2018) 106-114

37. United Nations Framework Convention on Climate Change (UNFCCC) 1994. UNFCCC Process: Convention, Kyoto Protocol and the Paris Agreement. https://unfccc.int

38. Ventura, F. Spano,VF. Duce, P and Snyder, RL. 1999. An evaluation of common evapotranspiration equations. Irrigation Science 18, 163-170

39. Zhang, B.; Liu, Y.; Xu, D.; Zhao, N.; Lei, B.; Rosa, R.D.; Paredes, P.; Paço, T.A.; Pereira, L.S. 2013.The dual crop coefficient approach to estimate and partitioning evapotranspiration of the winter wheat-summer maize crop sequence in North China Plain. Irrig. Sci. 31, 1303-1316.

40. Zuidema, P.A., Peter A. Leffelaar. P.A. Gerritsma, W, Mommer, L, Niels P.R. Anten, N.P.R. 2005. A physiological production model for cocoa (Theobroma cacao): model presentation, validation and application Agricultural Systems 84 (2005) 195-225

\section{Figures}

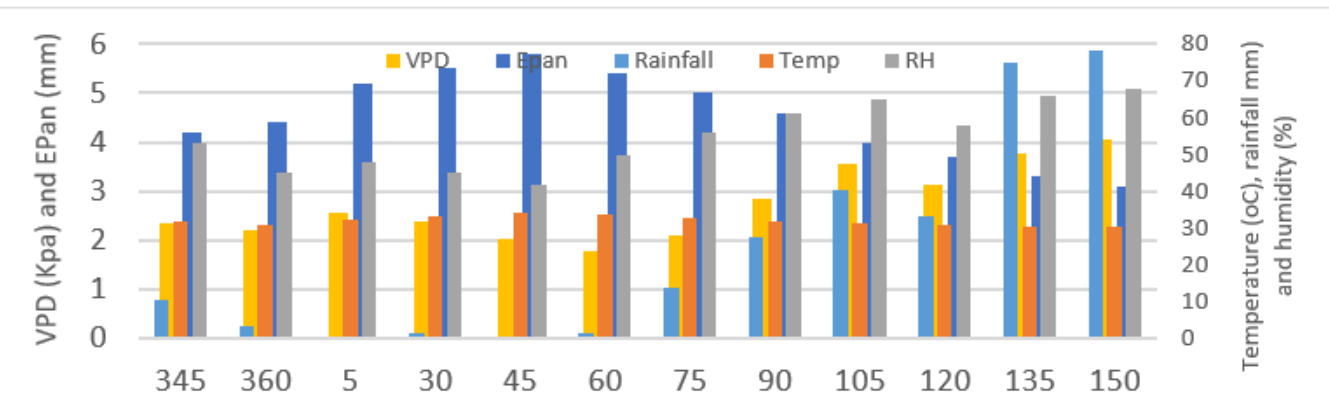

Fig.1. Weather varaiables during period of experiment (December to May)

\section{Figure 1}

Please See image above for figure legend. 


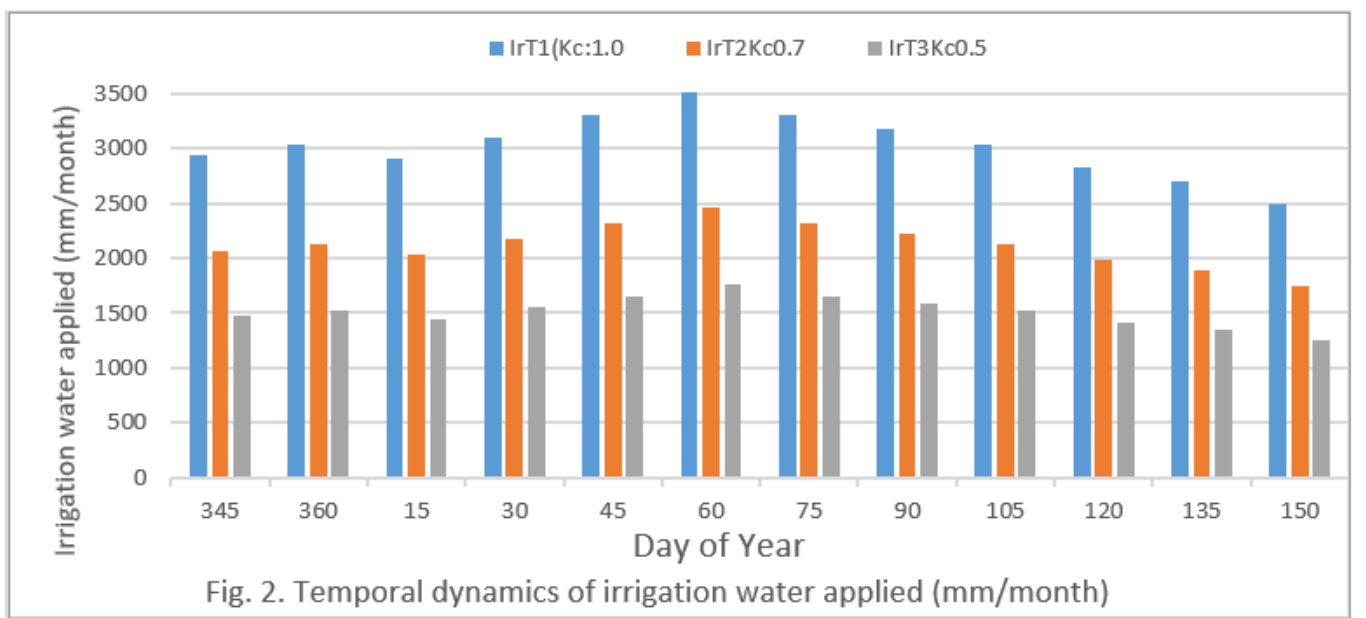

Figure 2

Please See image above for figure legend.

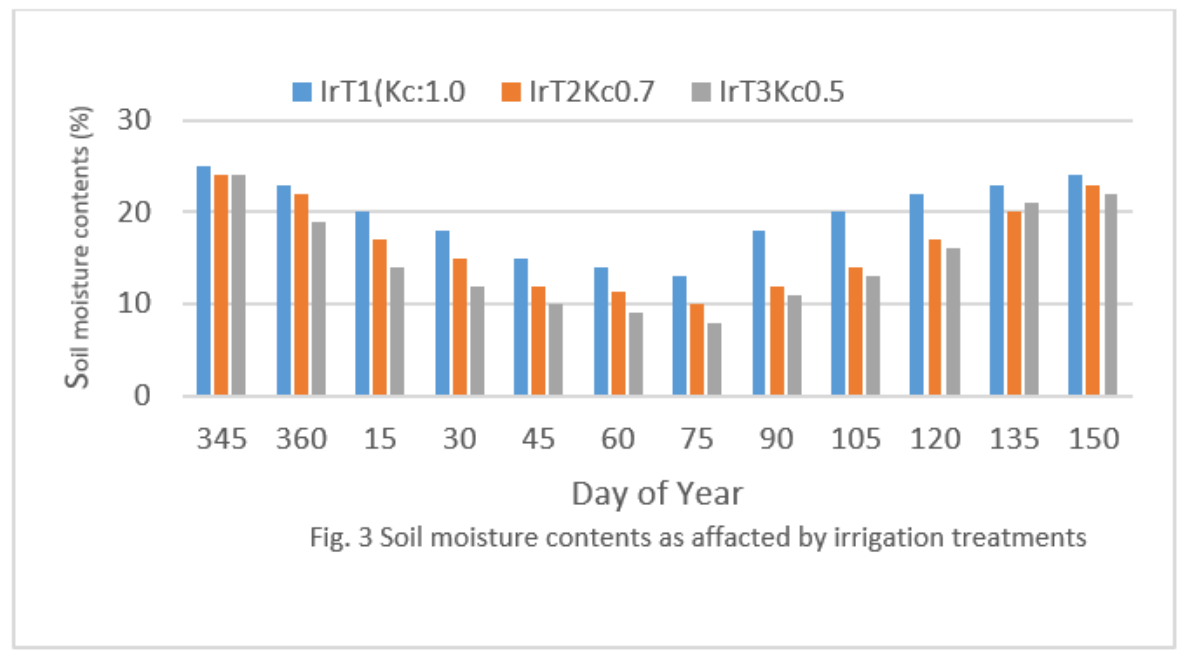

Figure 3

Please See image above for figure legend.

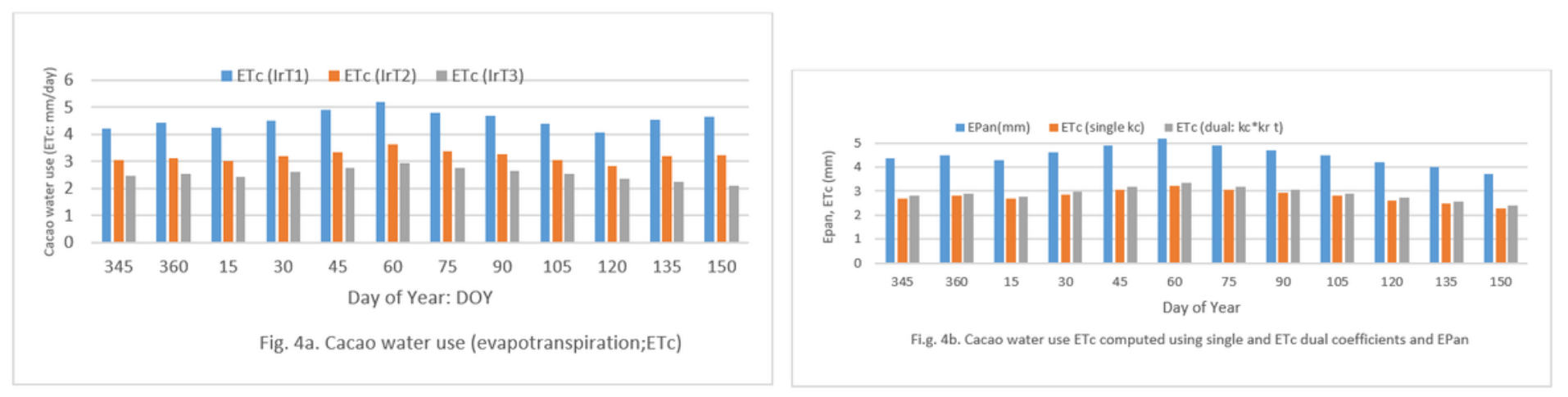

Figure 4

Please See image above for figure legend. 

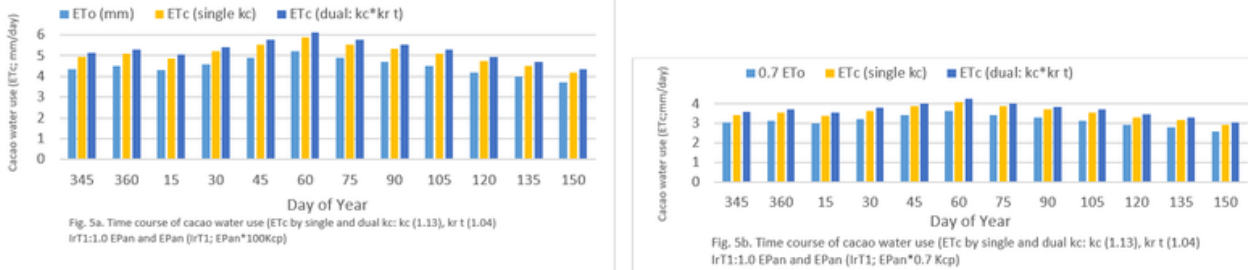

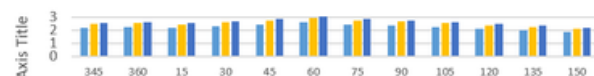

Day of Year

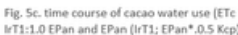

\section{Figure 5}

Please See image above for figure legend.

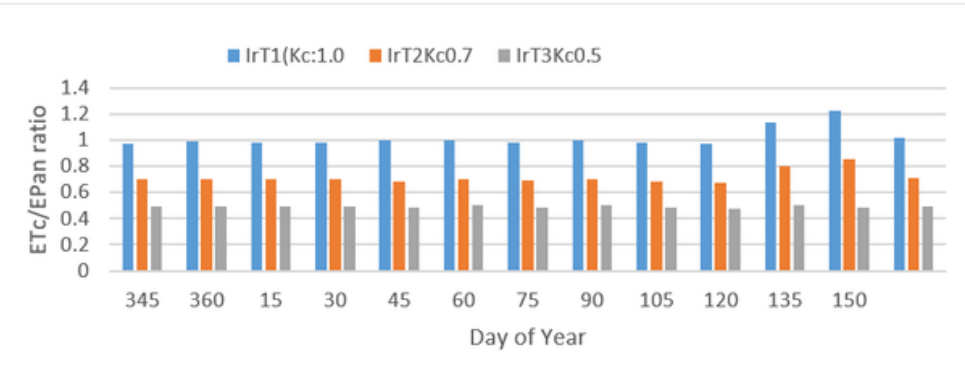

Fig. 6a. Ratio of cacao water use (ETc) to Pan evaporation (EPan)

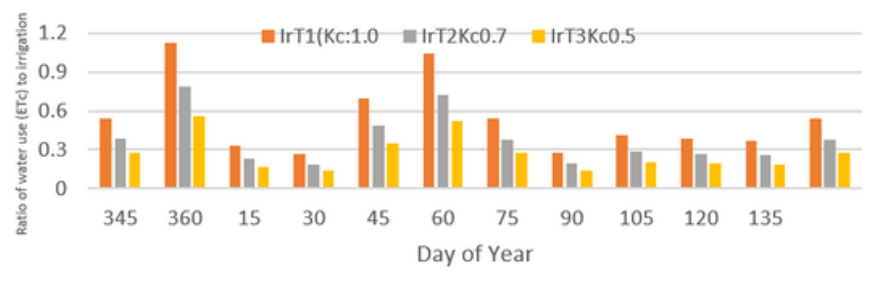

Fig. 6b. Ratio of cacao water use (ETc) to irrigation water applied

\section{Figure 6}

Please See image above for figure legend.

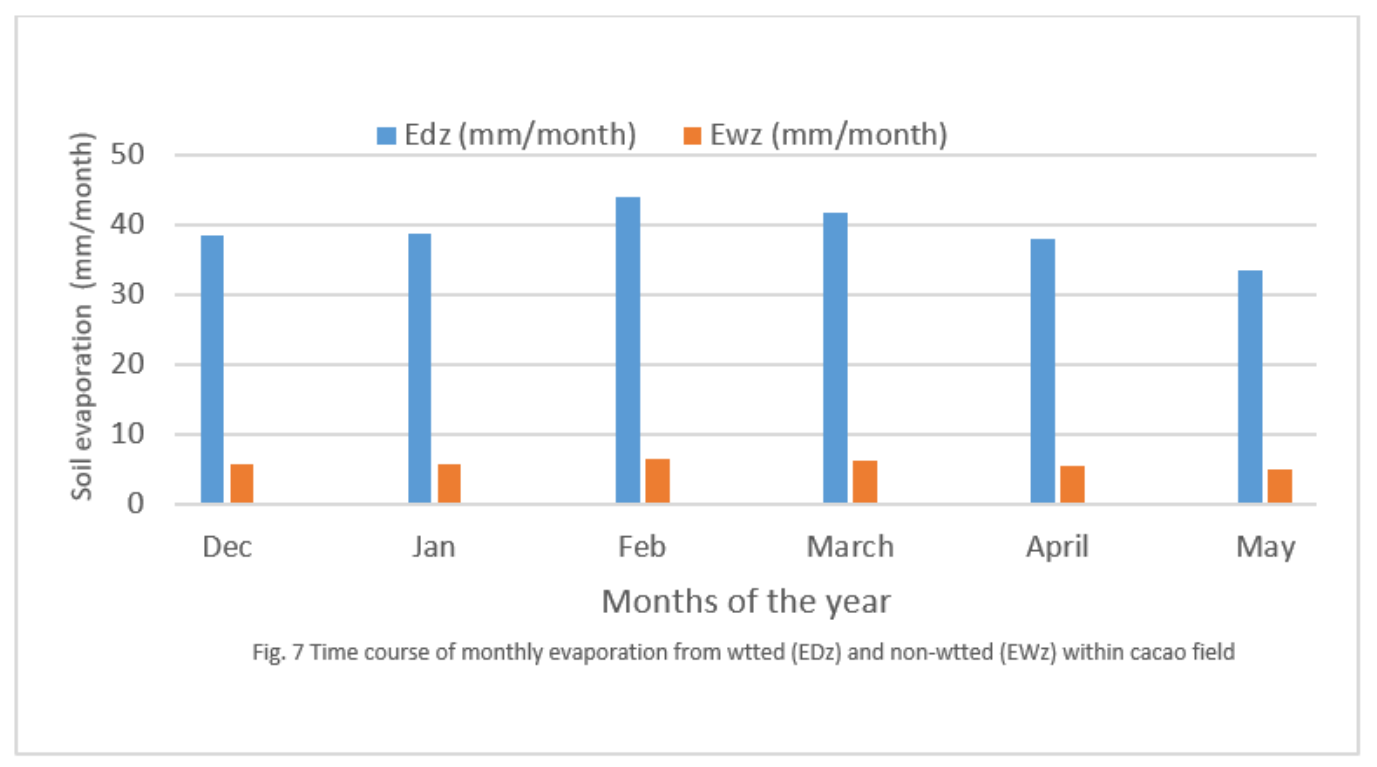

Figure 7

Please See image above for figure legend. 